Jurnal ABDIMAS INDEPENDEN

Vol. 1, No. 2, November 2020

\title{
MENUMBUHKAN JIWA KEWIRAUSAHAAN DAN PENYUSUNAN RENCANA BISNIS PADA PARA PEMUDA DI DESA KERUMUT KECAMATAN PRINGGABAYA KABUPATEN LOMBOK TIMUR
}

\author{
Rusminah $\mathrm{HS}^{1}$, Hilmiati ${ }^{2}$, Eddy Achmad ${ }^{3}$ \\ Jurusan Manajemen - Universitas Mataram \\ rosewahyu99@gmail.com
}

\begin{abstract}
ABSTRAK
Pengabdian pada masyarakat dengan judul "Menumbuhkan Jiwa Kewirausahaan Dan Penyusunan Rencana Bisnis Pada Para Pemuda Di Desa Kerumut Kecanatan Pringgabaya Kabupaten Lombok Timur" bertujuan untuk menumbukan mberikan penyuluhan dan bimbingan kepada para pedagang sayur keliling untuk dapat mengembangkan usahanya secara efektif dan efisien dan memberikan penyuluhan tentang pembukuan sederhana, sehingga para pedagang keliling dapat memperhitungkan semua biaya - biaya yang dikeluarkan dan dapat menghitung pendapatan yang diterima. Metode yang digunakan dalam penyuluhan adalah metode ceramah, tanya-jawab dan praktek. Pelaksanaan pengabdian pada masyarakat ini dilaksanakan pada hari Sabtu, 6 Oktober 2018 di awali dengan ceramah, tanya jawab dan dilanjutkan dengan praktek pembukuan sederhana. Materi yang disampaikan oleh tim pengabdian mendapatkan respon positif dari para peserta. Hal ini dapat dilihat dari kesungguhan pserta dalam mengikuti penyuluhan dan antusiasme peserta di dalam memberikan pertanyaan-pertanyaan pada sesi tanya jawab. Penyuluhan tentang pengembangan usaha dan pentingnya pembukuan sederhana ini, dinilai sangat positif dan bermanfaat karena sangat relevan dengan kebutuhan para pedagang sayur keliling saat ini, maka disarankan supaya kegiatan ini terus dikembangkan dan diperluas di lingkungan yang lain, sehingga para pedagang sayur keliling dapat meningkatkan pendapatannya,
\end{abstract}

Kata Kunci : Kewirausahaan, Rencana Bisnis. 


\begin{abstract}
Community service with the title "Growing Entrepreneurship And Developing Business Plan For Youth In The Kerumut Village Kecamatan Pringgabaya-Lombok Timur" aims to increase counseling and guidance to mobile vegetable traders to be able to develop their business effectively and efficiently. simple, so that the traveling traders can calculate all costs incurred and can calculate the income received. The methods used in extension are lecture, question and answer and practice methods. The implementation of this community service was carried out on Saturday, October 62018 starting with a lecture, question and answer and continued with simple bookkeeping practices. The material presented by the service team received a positive response from the participants. This can be seen from the seriousness of the participants in following the counseling and the enthusiasm of the participants in giving questions in the question and answer session. Counseling on business development and the importance of simple bookkeeping is considered very positive and useful because it is very relevant to the current needs of mobile vegetable traders, so it is suggested that this activity be continued to be developed and expanded in other environments, so that mobile vegetable traders can increase their income.
\end{abstract}

Keywords: entrepreneurship, business plan.

\title{
PENDAHULUAN
}

Pergantian dari era orde baru ke era reformasi yang disertai dengan krisis multidimensi mengakibatkan pengangguran di mana - mana. Perekonimian yang saat itu terpusat pada usaha-usaha besar dan konglomerasi mengalami kesulitan besar, Konglomerat mengalami kesulitan keuangan, Daya beli masyarakat turun dan perusahaan -perusahaan melakukan pemutusan hubungan kerja,

Di lain pihak ketidakpastian social politik begitu terasa, Semua orang merasa tidak pasti, Sistem pemerintahan berubah, acuan dan undang-undang berubah. Sikap masyarakat sangat agresif dan investor-investor asing maupun dalam negeri pergi meninggalkan Indonesia. Di tengah-tengah ketidakpastian itu para sarjana dan tamatan SMA kesulitan mencari pekerjaan. Sebagian besar tidak dapat ditampung.Mereka harus bersaing dengan mereka yang telah jauh 


\title{
Jurnal ABDIMAS INDEPENDEN
}

\author{
Vol. 1, No. 2, November 2020
}

berpengalaman dalam mencari kerja. Para sarjan dan tamatan SMA itupun menjadi pengangguran.

Demikian hal nya yang terjadi pada para pemuda di Desa Kerumut Kecamatan Pringgabaya Kabupaten Lombok Timur, Untuk menghindari ketidakpastian tersebut merka cenderung memilih menjadi tenaga kerja di Luar Negeri dan ada juga yang mencoba bertahan hidup membuka usaha kecil- kecil an dengan penghasilan yang tidak menentu. Semua fasilitas harus dibayar dari uamg yang dicari sendiri. Bahkan pada tahap-tahap awal membangun usaha, ditemui banyak kesulitan. Belum mempunyai keahlian yang memadai, apalagi kepercayaan. Semua itu harus dibangun setahap demi setahap yang diawali dengan berbagai tantangan.

Berdasarkan kenyataan tersebut, maka kegiatan pengabdian masyarakat ini berorientasi pada bagaimana menumbuhkan jiwa wirausaha dan penyusunan rencana bisnis.

\section{METODE KEGIATAN}

Para pemuda di desa Kerumut belum banyak yang memiliki keinginan dan kemauan untuk membuka usaha. Mereka cenderung untuk pergi ke luar negeri menjadi tenaga kerja Indonesia. Hal ini disebabkan belum adanya jiwa kewirausahaan yang ada pada diri mereka. Sebagian kecil dari mereka ada juga yang sudah mencoba untuk membuka usaha kecil - kecilan dengan penghasilan yang tidak menentu, karena keterbatasan modal dan keterbatasan kemampuan untuk berusaha. Begitu pula didalam merencanakan bisnis, mereka belum mampu untuk menyusun secara tepat

Untuk memecahkan masalah yang dihadapi oleh para pemuda di desa Kerumut, maka dipandang perlu untuk melakukan penyuluhan kepada para pemuda tentang bagaimana menumbuhkan semangat jiwa kewirausahaan dan penyusunan rencana bisnis. Adapun materi yang diberikan yang diberikan untuk 
menyelesaikan masalah tersebut adalah ; Menumbuhkan jiwa kewirausahaan, memulai usaha dan penyusunan rencana bisnis. Kegiatan ini diharapkan dapat menumbuhkan semangat jiwa wirausaha dan dapat menyusun rencana bisnis dan memulai usaha, sehingga usaha yang akan dijalan dapat tumbuh dan berkembang menjadi usaha yang dapat menopang kehidupan mereka

Metode kegiatan yang digunakan adalah metode ceramah, tanya jawab dan praktek. Sebagai nara sumber dalam pelatihan ini adalah tim Pengabdian Pada Masyarakat Fakultas Ekonomi dan Bisnis Universitas Mataram. Materi materi yang diberikan dalam kegiatan pengabdian masyarakat kepada masyarakat ini adalah :

1. Menumbuhkan jiwa kewirausahaan

2. Penyusunan rencana bisnis

3. Memulai usaha.

Antusiasme peserta dalam mengikuti kegiatan pengabdian ini sangat tinngi. Terlihat dari keaktifan para peserta di dalam mengajukan pertanyaanpertanyaan. Kegiatan pengabdian pada masyarakat dilaksanakan pada hari Jumat, tanggal 4 Oktober 2019 di Desa Kerumut Kecamatan Pringgabaya Kabupaten Lombok Timur.

Desa Kerumut merupakan salah satu Desa dari 15 desa yang ada di wilayah Kecamatan Pringgabaya Kabupaten Lombok Timur. Setelah terjadinya pemekaran Desa Kerumut pecah menjadi 2 (dua) yaitu desa Kerumut dan desa Anggareksa. Desa Kerumut terdiri dari 4 (empat) wilayah kekadusan, yaitu :

1. Wilayah Kekadusan Toron

2. Wilayah Kekadusan Gubek Daya

3. Wilayah Kekadusan Benteng

4. Wilayah Kekadusan Dasan Lendanag

Secara geografis desa Kerumut mempunyai luas wilayah $342 \mathrm{Ha}$. Memiliki letak geografis yang cukup strategis berada di atas ketinggian 0,25 Mdl dengan 


\section{Jurnal ABDIMAS INDEPENDEN}

Vol. 1, No. 2, November 2020

curah hujan $1,830 \mathrm{~mm} /$ tahun. Adapun batas-batas wilayah desa Kerumut Kecamatan Pringgabaya sbb:

1. Sebelah Utara : Desa Pohgading Timur

2. Sebelah Selatan : Desa Anggaraksa

3. Sebelah Timur : Selat alas

4. Sebelah Barat : Desa Apitaik

Sedangkan jumlah penduduk desa kerumut berjumlah 4.627 orang, dengan jumlah kepala keluarga sebanyak 1483 KK. Dari jumlah penduduk tersebut banyak para pemuda tamatan SMA dan sarjana S1 yang masih belum mendapatkan pekerjaan, sehingga ada yang bertahan hidup dengan membuka usaha ada juga yang menjadi tenaga kerja Indonesia di Negara Malasyia dan Saudi Arabia.

\section{HASIL DAN PEMBAHASAN}

Sebagaimana tema yang diangkat dalam pengabdian ini adalah menumbuhkan jiwa kewirausahaan dan penyusunan rencana bisnis pada para pemuda di desa Kerumut, maka diharapkan kegiatan ini mampu menumbuhkan semangat jiwa kewirausahaan dan mampu menyusun rencana bisnis. Menumbuhkan jiwa wirausaha kepada para pemuda diberikan pengarahan dan bimbingan untuk menyusun rencana bisnis, sehingga mereka mampu untuk menciptakan dan memulai usaha baru.

Adapun tips untuk menumbuhkan jiwa kewirausahaan diantaranya: Memulai bisnis dengan niat dan keyakinan, Memiliki kecepatan melihat peluang, mempelajari kisah sukses orang lain, modal, focus dalam berwirausaha, memiliki kemampuan menjual dan melakukan action langsung tanpa menunda - nunda.

Untuk memulai sebuah usaha baru diperlukan perencanann bisnis yang matang. Rencan bisnis merupakan sebuah gambaran rinci mengenai ide bisnis dalam bentuk dokumen sederhana yang tertulis, yang mencakup informasi status 
saat ini, kebutuhan mendatang, dan hasil yang diharapakan dari usaha atau bisnis baru tersebut.

Hal mendasar dalam membuat rencana bisnis yaitu diawali dengan membuat ide bisnis, ide bisnis sebagai jawaban, cara menghasilkan keuntungan, siapa pembeli produk anda, dana untuk memulai bisnis. Adapun komponen rencana bisnis terdiri dari ; ringkasan eksekutif (konsep bisnis, misi perusahaan, produk /jasa, target pasar, tim manajemen dan keuangan), deskrisi bisnis, strategi pemasaran, analisis persaingan, rencana desain dan pengembangan, rencana operasi dan manajemen, analisis rencana keuangan.

Memulai sebuah usaha merupakan langkah besar dan akan mengubah kehidupan kita, karenanya kita harus bertanggung jawab atas keberhasilannya dan ini berarti harus bekerja keras. Karena apabila berhasil akan dapat memuaskan dan memberikan keuntungan. Beberapa hal praktis didalam memulai usaha, antara lain, memilih nama dan membuat logo, memilih tempat usaha, membeli perlengkapan, pemenuhan terhadap mesin dan alat-alat produksi, merekrut pegawai, melakukan training persiapan uji coba hingga mempromosikan produk atau jasa yang dihasilkan,

Memulai usaha perlu ide yang cemerlang untuk menentukan pilihan usaha yang diinginkan. Ide usaha yang diiginkan haruslah cocok sesuai dengan kata hati, mampu melibatkan diri dalam hal-hal tehnis dan usaha yang akan diusahakan adalah usaha yang nantinya dapat menguntungkan. Materi - materi tersebut diberikan oleh tim pengabdian pada saat pengabdian kepada masyarakat dilaksanakan. 


\section{Jurnal ABDIMAS INDEPENDEN}

Vol. 1, No. 2, November 2020

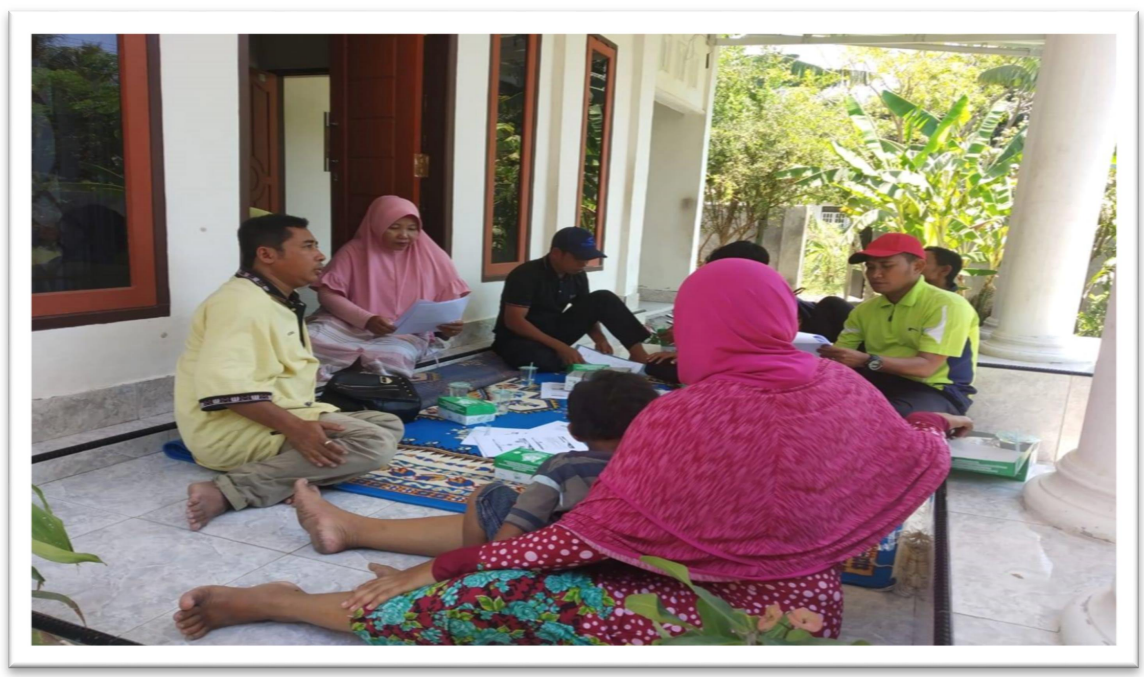

Gambar 1: Kegiatan Pengabdian

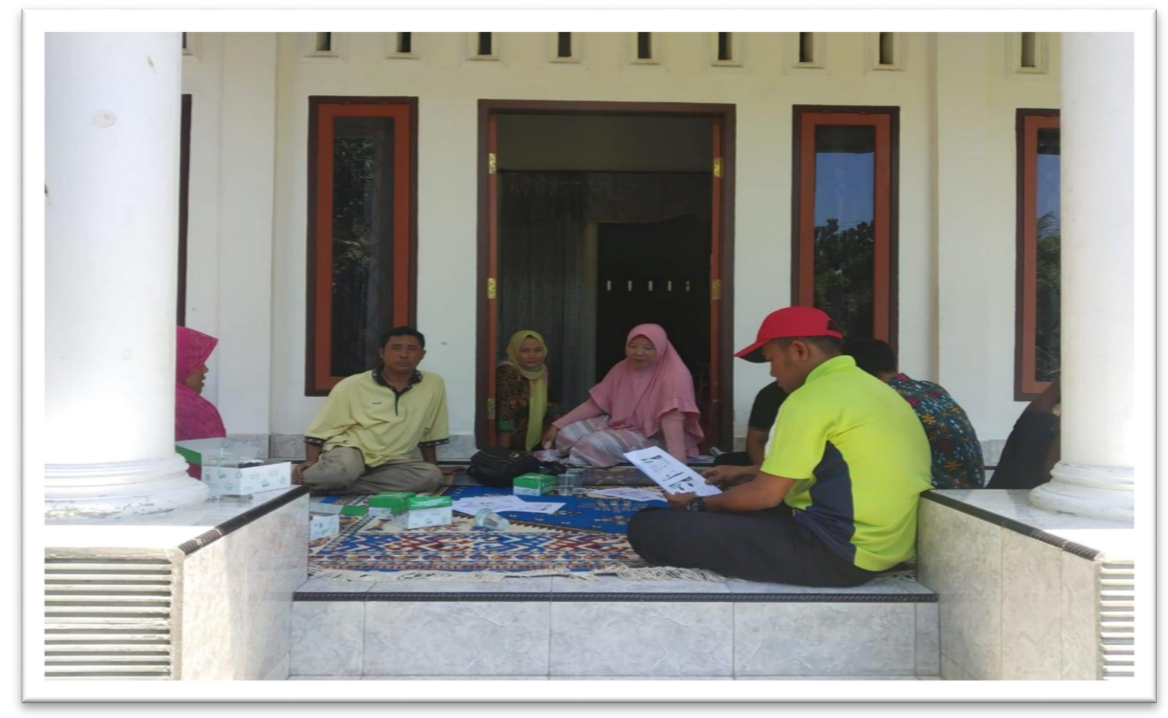

Gambar 2: Kegiatan Pengabdian

\section{KESIMPULAN DAN SARAN}

\section{Kesimpulan}

Menumbuhkan jiwa kewirusahaan kepada para pemuda di desa Kerumut dilakukan dengan memberikan motivasi yang tinggi dan dilengkapi dengan penyusunan rencana bisnis, dan langkah - langkah di dalam memulai usaha, sehingga usaha yang akan direncanakan akan dapat terarah dan berjalan lancar. 
Pengabdian masyarakat ini dinilai sangat positif dan bermanfaat karena sangat relevan dengan kebutuhan. Mereka berharap tidak hanya sekali tetapi terus dilakukan pembinaan agar usaha yang akan direncanakan nantinya dapat berkembang.

\section{Saran}

Pentingnya menumbuhkan jiwa kewirausahaan dan penyusunan rencana bisnis kepada para pemuda di desa kerumut, maka disarankan supaya kegiatan ini terus dikembangkan dan diperluas di desa -desa lain, sehingga para pemuda dapat tumbuh jiwa kewirausahaannya dan dapat merencanakan bisnis yang tepat dan menguntungkan.

\section{UCAPAN TERIMA KASIH}

Pelaksanaan kegiatan Pengabdian Kepada Masyarakat ini telah melibatkan berbagai pihak, oleh karena itu pada kesempatan ini kami mengucapkan terima kasih dan penghargaan yang setinggi tingginya kepada :

1. LPPM UNRAM selaku koordinator pelaksanaan pengabdian kepada masyarakat.

2. Fakultas Ekonomi dan Bisnis Universitas Mataram dan BP2EB Fakultas Ekonomi dan Bisnis Universitas Mataram.

3. Kepala Desa Kerumut dan para Pemuda di Desa Kerumut Kecamatan Pringgabaya Kabupaten Lombok Timur.

\section{DAFTAR PUSTAKA}

Husein, Martani.1993. Pengembangan Usaha Berskala Usaha Kecil di Indonesia. Indriyo Gitosudarmo. 1996. Pengantar Bisnis Modern Edisi 2, PT. BPFE, Yogyakarta.

Mansur, MH, dkk, 1989. Bimbingan Bisnis, Penerbit CV. Bintang Remaja, Surabaya.

Rhenal D Kasali ,dkk,2010. Modul Kewirausahaan, Rumah Perubahan. Jakarta. 